\title{
EVALUATING THE PERFORMANCE OF THE MEISSAN WATER DIRECTORATE USING THE EUROPEAN EXCELLENCE STANDARD (EFQM)
}

\author{
*Lecturer Doctor. HanadiSegerMakttoof ,**Researcher Ashwaq Ali Hussien \\ "University of Baghdad / College of Administration and Economics
}

DOI: $10.37648 / \mathrm{ijrssh} . v 10 \mathrm{i} 01.002$

Received: 05 ${ }^{\text {th }}$ September, 2019; Accepted:05th October, 2019; Published: $29^{\text {th }}$ October, 2019

\begin{abstract}
The current research aims to identify the reality of the Maysan Water Directorate and to determine the overall level of work if it is consistent with the requirements of applying the European Excellence Model, and 30 questionnaire forms have been distributed to the staff of the Department and statistical analysis has been conducted through SPSS, and have been valuable (Cronbach's Alpha). Has reached (0.982), This indicates that the measure is done in an appropriate internal consistency and with a high level of stability, which indicates the reliability and reliability of the data, and the research has found that there is a weakness in comparing the objectives achieved with the targets set for the determination of performance indicators with the clear definition of the cause and effect relationship. The researcher therefore recommends that a mechanism be established to compare the objectives achieved with those set.
\end{abstract}

Key Words: Performance, Performance Assessment, EFQM

THE FIRST SECTION /RESEARCH METHODOLOGY

First: The problem of research

Many of the Iraqi service and non-service institutions suffer from many problems because they do not match the modern management methods applied in the modern international system, Most organizations strive to keep pace with developments in order to achieve excellence in their services, but they are unable to do so because they do not have the assets to achieve excellence, They also lack assessments that enable them to know where their strengths and weaknesses are, and to know what has been achieved in comparison with what is planned.

The research problem is highlighted by the following questions:

1- What is the applicability of the ETP model in the Meissan Water Directorate?

2- What are the requirements for applying the European model of excellence in the Meissan Water Directorate? 
3- How can the Directorate of Water Meisan monitor performance and develop it in a manner consistent with recent administrative developments?

\section{Second : The importance of research}

The importance of the current research comes from the importance of applying the European model of excellence in a service department that is considered one of the most important departments for the citizen, which helps the administration of Meissan Water Directorate to adopt a modern approach in its work. In addition to providing a database, the Maysan Water Directorate helps the study sample to make appropriate decisions that improve the quality of its services.

\section{Third : The research aims}

to achieve the following:

1- To identify the reality of the Maysan Water Directorate and to determine the level of work in general if it is consistent with the requirements of the European model.

2- Identify the concept of institutional performance evaluation, as well as the importance of evaluating the performance of institutions and the objectives to be achieved by evaluating the institution.

3- Identify the concept of institutional excellence and its importance for institutions.

Fourth : Describe the research community and its identity

A random sample of research has been selected by the Directorate of Water Maysan, which is represented by the Directors-General, their assistants, working experts, the Higher Certificate Campaign in the Directorate, department directors, their assistants and the people's directors as scientific and strategic leaders of their ministry, and the resolution has been distributed to (30) Staff at the same location and the researcher has found good cooperation from the sample.

\section{Fifth: Honesty and stability}

Stability test indicates internal consistency and means that the scale is for a general purpose (Sekaran\&Bougie,
2010) indicated that the value (Cronbach's Alpha) if it is equal to or higher than $(0.60)$ is acceptable and that the scale has an appropriate internal consistency that can be repeated again to give the same results. Using the statistical program (SPSS.23), the value of (Cronbach's Alpha) is (0.982), which indicates that the standard has an appropriate internal consistency and a high level of stability, which means that the results can be trusted.

\section{SECOND SECTION / THEORETICAL BACKGROUND}

\section{First: Institutional performance evaluation}

\section{The concept of institutional performance evaluation}

The institutional evaluation process is one of the most important operations of organizations seeking excellence, quality and continuous development, as institutional evaluation is defined as a set of procedures by a team of stakeholders to determine the strengths needed to develop and improve the internal performance of the organization according to certain criteria (Al-dojni, 2010:10).

The performance appraisal reflects the experience of the Organization in how to properly invest its resources in a manner consistent with the achievement of a high level of performance at the right time, quality and at the lowest possible cost (Armstrong \& Taylor, $2016: 334$ ).

A complementary process that combines internal and external environmental indicators and draws a clear picture of the organization's output that the client is seeking in a way that reflects a positive image of the organization (Al-Dujaili, 2017:28).

\section{Importance of institutional evaluation}

The importance of evaluating institutional performance comes from its great role in ensuring that the objectives, which represent the efficient use of available resources, whether financial or human, have been properly achieved, i.e. ensuring that control is effective, by demonstrating how those resources are handled during the current period. And how successful or failing that control is in achieving the actual objectives, as well as helping to control plans for the next period (Mohammed, 2017: 106). 
Institutional evaluation also plays a role in obtaining efficient staff and institutional evaluation is an important factor in determining the talents and abilities of individuals, helping individuals to know the objectives of the organization, facilitating the management's mission to perform its tasks efficiently and moving away from activities that lead to waste and waste in the organization's resources (Dahkoul, 2018:84).

\section{Objectives for the evaluation of institutional performance}

The performance appraisal process aims to provide qualitative and quantitative data that is a strategic tool for the purpose of recognizing the organization's performance transparently and improving that performance if any weaknesses are found (Buyukozkan\&Karabulut, 2018:254).

\section{Second: The European Standard of Excellence}

\section{Concept of institutional excellence}

Institutional excellence has been created to reflect the need for an integrated and holistic approach to all elements and components of institution-building to achieve high capacity to address the surrounding external variables and situations, and to achieve coherence between their components and their own components, to invest their core capacity and to realize benefits for stakeholders in institutions and society at large (Al-Silmi, 2002:20).

Institutional excellence can be defined as a state of excellence in delivering all services efficiently and effectively, through mechanisms that ensure continuous progress in all respects and at all levels, and maintain this distinction by keeping pace with developments on a continuous basis (Hijazi, 2016:10)

The research believes that institutional excellence is a concept that reflects the quality of enterprise services in the services provided by them, as it is a comprehensive approach to practices that are innovative and distinctive, through which the enterprise is highly competitive and highly competitive.
To define this importance through the institutional set of facts, institutions seeking to achieve a distinct level of performance should consider them as follows (Al-Soudi, 2008: 264):

A. They need means and methods to identify obstacles they face in the event they arise.

B. Continuously develop its members, whether managers or employees, so that they can make the organization the most outstanding in performance compared to other competitors.

The importance of organizational excellence also stems from the ability of organizations to shape the forces supporting excellence by achieving rapid change rates, unlimited competition, maintaining organizational standing, and then increasing the sense of quality and their ability to employ technology (Alnsoor, 2010:32).

\section{The European Model of Excellence}

was created in 1991 by the European Foundation for Quality Management, a model of excellence in business and the application of comprehensive quality management principles in European institutions and countries. The award is awarded to four categories (AlMadhoun, 2014 : 87)

- Large institutions.

- The services and operating units of the institutions.

- Public sector institutions.

- Small and medium-sized enterprises.

\section{THIRD SECTION / PRACTICAL}

\section{First: Analysis of personal (demographic) variables}

This paragraph aims to clarify the characteristics of the researchers in the Meissan Water Directorate and their respective ratio of the total research sample (30) associated with them, as shown in table (1) and as follows: 
Table (1) Search community properties

\begin{tabular}{|c|c|c|c|c|}
\hline percentage & the number & Class distribution & Variables & $\mathbf{T}$ \\
\hline $\mathbf{7 3 . 3} \%$ & 22 & Mention & \multirow{2}{*}{ Gender } & \multirow{2}{*}{1} \\
\hline $26.7 \%$ & 8 & female & & \\
\hline $100 \%$ & 30 & & Total & \\
\hline $0 \%$ & 0 & Less than 25 years & \multirow{3}{*}{ age categories } & \multirow{3}{*}{2} \\
\hline $53.3 \%$ & 16 & 40- Hey.26 & & \\
\hline $46.7 \%$ & 14 & 41 years and over & & \\
\hline $100 \%$ & 30 & & Total & \\
\hline $0 \%$ & 0 & .Ph.D & \multirow{5}{*}{ Qualification } & \multirow{5}{*}{3} \\
\hline $0 \%$ & 0 & M.A & & \\
\hline $13.3 \%$ & 4 & Higher Diploma & & \\
\hline $46.7 \%$ & 14 & BA & & \\
\hline $40.0 \%$ & 12 & Less than that & & \\
\hline $100 \%$ & 30 & & Total & \\
\hline $10.0 \%$ & 3 & 5 years and less & \multirow{7}{*}{$\begin{array}{l}\text { Years of } \\
\text { service }\end{array}$} & \multirow{7}{*}{4} \\
\hline $26.7 \%$ & 8 & 10- Hey. 6 & & \\
\hline $20.0 \%$ & 6 & 15- Hey.11 & & \\
\hline $16.7 \%$ & 5 & 20- Hey.16 & & \\
\hline $13.3 \%$ & 4 & 25- Hey.21 & & \\
\hline $6.7 \%$ & 2 & $30-26$ & & \\
\hline $6.7 \%$ & 2 & years and over 31 & & \\
\hline $100 \%$ & 30 & & Total & \\
\hline
\end{tabular}

\section{Characteristics of the Research Society (Meisan Water Directorate) :}

1- Sex : The general information table for the research sample indicates that the sample varies with the male/female ratio in terms of responsibility, with the number of males (22) equal to $(73.3 \%)$ and the number of females (8) associated with $(26.7 \%)$

-2 age groups: It is noted that the age group (26-40) has the highest rates of $(53.3 \%)$, followed by (41 years and above) and (46.7\%) and (under 25 years). The number of students in the university is about $50 \%$, and the number of students in the university is about 50\% 30 years in which an experienced worker is provided.

3- According to the scientific qualification: The results of the statistical analysis of the scientific qualification for the research sample, as shown in the table above, show that the large proportion of the research sample is $46.7 \%$, and the holders of the bachelor's degree $(13.3 \%)$ have the lowest percentage, and the holders of a certificate (less).
This is why the diploma and the preparatory certificate was meant to be a percentage $(40 \%)$, which indicates that the Directorate relies in its superior and middle management on the holders of higher and experienced certificates.

4- By year of service: Statistical analysis results for years of service and as shown in the above table show that the highest percentage $(26.7 \%)$ of those with a service term of (6-10) years, whereas the proportion of those with a service term of (26-30 years) and (31 years and above) was equal $(6.7 \%)$, the lowest, The other categories were mixed, and the ratios showed that in the upper and middle administrations, the Directorate relied on those with experience in the field of work.

Second: Analyzing the results of the answers to the arithmetic mean, the normative deviation, and the agreement ratio for the performance evaluation axes

This paragraph included an analysis of the resolution responses distributed to the departments concerned in the 
Directorate of Upper and Central Departments and the purpose of the resolution was to present the evaluation of the available performance reached by the researcher by evaluating the Directorate's institutional performance using the EFQM model and to determine the extent and interest of these bodies in these opportunities for each axis and as it comes :

Table (2) Frequency of answer, mean, standard deviation, and agreement ratio of performance evaluation axes

\begin{tabular}{|l|c|c|c|c|c|c|c|c|c|}
\hline $\begin{array}{c}\text { Agreement } \\
\% \text { Rate }\end{array}$ & $\begin{array}{c}\text { standard } \\
\text { deviation }\end{array}$ & $\begin{array}{c}\text { Arithmetic } \\
\text { mean }\end{array}$ & $\begin{array}{c}\text { I do not } \\
\text { agree at } \\
\text { all }\end{array}$ & $\begin{array}{c}\text { I do } \\
\text { not } \\
\text { agree }\end{array}$ & $\begin{array}{c}\text { To } \\
\text { some } \\
\text { extent }\end{array}$ & Agreed & $\begin{array}{c}\text { Very } \\
\text { agree }\end{array}$ & Paragraphs \\
\hline \multicolumn{7}{|l|}{} \\
\hline $\mathbf{0 . 8 7 \%}$ & 0.81 & 4.37 & 0 & 1 & 3 & 10 & 16 & $\mathbf{1}$ \\
\hline $\mathbf{0 . 9 7 \%}$ & 0.53 & 4.70 & 0 & 0 & 1 & 7 & 22 & $\mathbf{2}$ \\
\hline $\mathbf{0 . 9 0} \%$ & 0.77 & 4.57 & 0 & 1 & 2 & 6 & 21 & $\mathbf{3}$ \\
\hline $\mathbf{0 . 9 0} \%$ & 0.67 & 4.40 & 0 & 0 & 3 & 12 & 15 & $\mathbf{4}$ \\
\hline $\mathbf{0 . 5 3} \%$ & 0.82 & 4.43 & 0 & 1 & 3 & 8 & 8 & $\mathbf{5}$ \\
\hline $\mathbf{0 . 8 7} \%$ & 0.72 & 4.37 & 0 & 0 & 4 & 11 & 15 & $\mathbf{6}$ \\
\hline $\mathbf{0 . 8 3} \%$ & 0.86 & 4.40 & 0 & 1 & 4 & 7 & 18 & $\mathbf{7}$ \\
\hline $\mathbf{0 . 7 3} \%$ & 0.88 & 4.30 & 0 & 0 & 8 & 5 & 17 & $\mathbf{8}$ \\
\hline $\mathbf{0 . 8 3} \%$ & 0.96 & 4.33 & 0 & 1 & 4 & 8 & 17 & $\mathbf{9}$ \\
\hline $\mathbf{0 . 8 3} \%$ & 0.78 & 4.43 & & & Total \\
\hline
\end{tabular}

\begin{tabular}{|l|c|c|c|c|c|c|c|c|}
\hline $\begin{array}{c}\text { Agreement } \\
\% \text { Rate }\end{array}$ & $\begin{array}{c}\text { standard } \\
\text { deviation }\end{array}$ & $\begin{array}{c}\text { Arithmetic } \\
\text { mean }\end{array}$ & $\begin{array}{c}\text { I do not } \\
\text { agree at } \\
\text { all }\end{array}$ & $\begin{array}{c}\text { I do } \\
\text { not } \\
\text { agree }\end{array}$ & $\begin{array}{c}\text { To } \\
\text { some } \\
\text { extent }\end{array}$ & Agreed & $\begin{array}{c}\text { Very } \\
\text { agree }\end{array}$ & Paragraphs \\
\hline \multicolumn{7}{|l|}{} \\
\hline $\mathbf{0 . 8 0} \%$ & 0.76 & 4.20 & 0 & 0 & 6 & 12 & 12 & $\mathbf{1}$ \\
\hline $\mathbf{0 . 9 0} \%$ & 0.61 & 4.20 & 0 & 0 & 3 & 18 & 9 & $\mathbf{2}$ \\
\hline $\mathbf{0 . 7 3} \%$ & 0.87 & 4.27 & 0 & 0 & 8 & 6 & 16 & $\mathbf{3}$ \\
\hline $\mathbf{0 . 7 7} \%$ & 0.91 & 4.27 & 0 & 1 & 6 & 7 & 16 & $\mathbf{4}$ \\
\hline $\mathbf{0 . 7 3} \%$ & 0.94 & 4.23 & 0 & 1 & 7 & 6 & 16 & $\mathbf{5}$ \\
\hline $\mathbf{0 . 7 0} \%$ & 0.89 & 4.03 & 0 & 1 & 8 & 10 & 11 & $\mathbf{6}$ \\
\hline $\mathbf{0 . 7 3} \%$ & 0.90 & 4.13 & 0 & 1 & 7 & 9 & 13 & $\mathbf{7}$ \\
\hline $\mathbf{0 . 7 7} \%$ & 0.84 & 4.19 & & & Total & & & \\
\hline
\end{tabular}




\begin{tabular}{|l|c|c|c|c|c|c|c|c|c|}
\hline $\begin{array}{c}\text { Agreement } \\
\% \text { Rate }\end{array}$ & $\begin{array}{c}\text { standard } \\
\text { deviation }\end{array}$ & $\begin{array}{c}\text { Arithmetic } \\
\text { mean }\end{array}$ & $\begin{array}{c}\text { I do not } \\
\text { agree at } \\
\text { all }\end{array}$ & $\begin{array}{c}\text { I do } \\
\text { not } \\
\text { agree }\end{array}$ & $\begin{array}{c}\text { To } \\
\text { some } \\
\text { extent }\end{array}$ & Agreed & $\begin{array}{c}\text { Very } \\
\text { agree }\end{array}$ & Paragraphs \\
\hline \multicolumn{7}{|l|}{} \\
\hline $\mathbf{0 . 9 3} \%$ & 0.62 & 4.60 & 0 & 0 & 2 & 8 & 20 & $\mathbf{1}$ \\
\hline $\mathbf{0 . 8 7} \%$ & 0.82 & 4.43 & 0 & 1 & 3 & 8 & 18 & $\mathbf{2}$ \\
\hline $\mathbf{0 . 9 3} \%$ & 0.62 & 4.60 & 0 & 0 & 2 & 8 & 20 & $\mathbf{3}$ \\
\hline $\mathbf{0 . 9 0} \%$ & 0.68 & 4.53 & 0 & 0 & 3 & 8 & 19 & $\mathbf{4}$ \\
\hline $\mathbf{0 . 7 7 \%}$ & 0.96 & 4.20 & 0 & 2 & 5 & 8 & 15 & $\mathbf{5}$ \\
\hline $\mathbf{0 . 7 7} \%$ & 0.82 & 4.23 & 0 & 0 & 7 & 9 & 14 & $\mathbf{6}$ \\
\hline $\mathbf{0 . 7 3} \%$ & 0.96 & 4.10 & 0 & 2 & 6 & 9 & 13 & $\mathbf{7}$ \\
\hline $\mathbf{0 . 8 7} \%$ & 0.69 & 4.27 & 0 & 0 & 4 & 14 & 12 & $\mathbf{8}$ \\
\hline $\mathbf{0 . 7 7} \%$ & 0.89 & 4.20 & 0 & 1 & 6 & 9 & 14 & $\mathbf{9}$ \\
\hline $\mathbf{0 . 8 4} \%$ & 0.78 & 4.35 & & & \multicolumn{2}{|c|}{ Total } \\
\hline
\end{tabular}

\begin{tabular}{|l|c|c|c|c|c|c|c|c|c|}
\hline $\begin{array}{c}\text { Agreement } \\
\% \text { Rate }\end{array}$ & $\begin{array}{c}\text { standard } \\
\text { deviation }\end{array}$ & $\begin{array}{c}\text { Arithmetic } \\
\text { mean }\end{array}$ & $\begin{array}{c}\text { I do not } \\
\text { agree at } \\
\text { all }\end{array}$ & $\begin{array}{c}\text { I do } \\
\text { not } \\
\text { agree }\end{array}$ & $\begin{array}{c}\text { To } \\
\text { some } \\
\text { extent }\end{array}$ & Agreed & \multicolumn{2}{c|}{$\begin{array}{c}\text { Axis IV: Partnerships and resources } \\
\text { agree }\end{array}$} & Paragraphs \\
\hline \multicolumn{7}{|c|}{} \\
\hline $\mathbf{0 . 7 7 \%}$ & 0.79 & 4.17 & 0 & 0 & 7 & 11 & 12 & $\mathbf{1}$ \\
\hline $\mathbf{0 . 9 3} \%$ & 0.72 & 4.40 & 0 & 1 & 1 & 13 & 15 & $\mathbf{2}$ \\
\hline $\mathbf{0 . 8 7} \%$ & 0.72 & 4.40 & 0 & 0 & 4 & 10 & 16 & $\mathbf{3}$ \\
\hline $\mathbf{0 . 9 0} \%$ & 0.86 & 4.40 & 0 & 2 & 1 & 10 & 17 & $\mathbf{4}$ \\
\hline $\mathbf{0 . 8 3} \%$ & 0.71 & 4.20 & 0 & 0 & 5 & 14 & 11 & $\mathbf{5}$ \\
\hline $\mathbf{0 . 8 7} \%$ & 0.79 & 4.30 & 0 & 1 & 3 & 12 & 14 & $\mathbf{6}$ \\
\hline $\mathbf{0 . 8 7} \%$ & 0.78 & 4.27 & 0 & 1 & 3 & 13 & 13 & $\mathbf{7}$ \\
\hline $\mathbf{0 . 8 0} \%$ & 0.98 & 4.27 & 1 & 0 & 5 & 8 & 16 & $\mathbf{8}$ \\
\hline $\mathbf{0 . 8 7} \%$ & 0.72 & 4.40 & 0 & 0 & 4 & 10 & 16 & $\mathbf{9}$ \\
\hline $\mathbf{0 . 7 7} \%$ & 0.96 & 4.10 & 1 & 0 & 6 & 11 & 12 & $\mathbf{1 0}$ \\
\hline $\mathbf{0 . 8 5} \%$ & 0.80 & 4.29 & & & Total & & & \\
\hline
\end{tabular}

\begin{tabular}{|c|c|c|c|c|c|c|c|c|}
\hline $\begin{array}{c}\text { Agreement } \\
\% \text { Rate }\end{array}$ & $\begin{array}{l}\text { standard } \\
\text { deviation }\end{array}$ & $\begin{array}{c}\text { Arithmetic } \\
\text { mean }\end{array}$ & $\begin{array}{l}\text { I do not } \\
\text { agree at } \\
\text { all }\end{array}$ & $\begin{array}{c}\text { I do } \\
\text { not } \\
\text { agree }\end{array}$ & $\begin{array}{c}\text { To } \\
\text { some } \\
\text { extent }\end{array}$ & Agreed & $\begin{array}{c}\text { Very } \\
\text { agree }\end{array}$ & Paragraphs \\
\hline \multicolumn{9}{|c|}{ Fifth Axis: Operations and Services } \\
\hline 0.93 & 0.61 & 4.37 & 0 & 0 & 2 & 15 & 13 & 1 \\
\hline $0.90 \%$ & 0.67 & 4.40 & 0 & 0 & 3 & 12 & 15 & 2 \\
\hline $0.73 \%$ & 0.88 & 4.10 & 0 & 1 & 7 & 10 & 12 & 3 \\
\hline $0.63 \%$ & 0.93 & 3.97 & 0 & 1 & 10 & 8 & 11 & 4 \\
\hline $0.77 \%$ & 0.84 & 4.30 & 0 & 0 & 7 & 7 & 16 & 5 \\
\hline $0.83 \%$ & 0.83 & 4.27 & 0 & 1 & 4 & 11 & 14 & 6 \\
\hline $0.87 \%$ & 0.88 & 4.30 & 0 & 2 & 2 & 11 & 15 & 7 \\
\hline $0.81 \%$ & 0.81 & 4.24 & & & Total & & & \\
\hline
\end{tabular}




\begin{tabular}{|c|c|c|c|c|c|c|c|c|}
\hline $\begin{array}{l}\text { Agreement } \\
\text { \%Rate }\end{array}$ & $\begin{array}{l}\text { standard } \\
\text { deviation }\end{array}$ & $\begin{array}{c}\text { Arithmetic } \\
\text { mean }\end{array}$ & $\begin{array}{l}\text { I do not } \\
\text { agree at } \\
\text { all }\end{array}$ & $\begin{array}{l}\text { I do } \\
\text { not } \\
\text { agree }\end{array}$ & $\begin{array}{c}\text { To } \\
\text { some } \\
\text { extent }\end{array}$ & Agreed & $\begin{array}{c}\text { Very } \\
\text { agree }\end{array}$ & Paragraphs \\
\hline \multicolumn{9}{|c|}{ Sixth axis: customer results } \\
\hline $0.93 \%$ & 0.63 & 4.53 & 0 & 0 & 2 & 10 & 18 & 1 \\
\hline $0.90 \%$ & 0.77 & 4.40 & 0 & 1 & 2 & 11 & 16 & 2 \\
\hline $0.90 \%$ & 0.67 & 4.40 & 0 & 0 & 3 & 12 & 15 & 3 \\
\hline $0.93 \%$ & 0.63 & 4.53 & 0 & 0 & 2 & 10 & 18 & 4 \\
\hline $0.90 \%$ & 0.77 & 4.40 & 0 & 1 & 2 & 11 & 16 & 5 \\
\hline $0.73 \%$ & 0.94 & 4.23 & 0 & 1 & 7 & 6 & 16 & 6 \\
\hline $0.83 \%$ & 0.75 & 4.30 & 0 & 0 & 5 & 11 & 14 & 7 \\
\hline $0.87 \%$ & 0.74 & 4.40 & \multicolumn{5}{|c|}{ Total } & \\
\hline
\end{tabular}

\begin{tabular}{|c|c|c|c|c|c|c|c|c|}
\hline $\begin{array}{c}\text { Agreement } \\
\% \text { Rate }\end{array}$ & $\begin{array}{c}\text { standard } \\
\text { deviation }\end{array}$ & $\begin{array}{c}\text { Arithmetic } \\
\text { mean }\end{array}$ & $\begin{array}{c}\text { I do not } \\
\text { agree at } \\
\text { all }\end{array}$ & $\begin{array}{c}\text { I do } \\
\text { not } \\
\text { agree }\end{array}$ & $\begin{array}{c}\text { To } \\
\text { some } \\
\text { extent }\end{array}$ & Agreed & $\begin{array}{c}\text { Very } \\
\text { agree }\end{array}$ & Paragraphs \\
\hline \multicolumn{7}{|c|}{ Seventh Axis: Results of Employees } \\
\hline $\mathbf{1 0 0} \%$ & 0.47 & 4.70 & 0 & 0 & 0 & 9 & 21 & $\mathbf{1}$ \\
\hline $\mathbf{0 . 8 7} \%$ & 0.90 & 4.23 & 0 & 1 & 3 & 13 & 13 & $\mathbf{2}$ \\
\hline $\mathbf{0 . 8 3} \%$ & 0.76 & 4.33 & 0 & 0 & 5 & 10 & 15 & $\mathbf{3}$ \\
\hline $\mathbf{0 . 9 7} \%$ & 0.65 & 4.30 & 0 & 1 & 0 & 18 & 11 & $\mathbf{4}$ \\
\hline $\mathbf{0 . 9 3} \%$ & 0.63 & 4.47 & 0 & 0 & 2 & 12 & 16 & $\mathbf{5}$ \\
\hline $\mathbf{0 . 9 7} \%$ & 0.56 & 4.63 & 0 & 0 & 1 & 9 & 20 & $\mathbf{6}$ \\
\hline $\mathbf{0 . 8 3} \%$ & 0.76 & 4.33 & 0 & 0 & 5 & 10 & 15 & $\mathbf{7}$ \\
\hline $\mathbf{0 . 9 1} \%$ & 0.68 & 4.43 & \multicolumn{7}{|c|}{ Total } \\
\end{tabular}

\begin{tabular}{|c|c|c|c|c|c|c|c|c|}
\begin{tabular}{|} 
Agreement \\
$\%$ Rate
\end{tabular} & $\begin{array}{c}\text { standard } \\
\text { deviation }\end{array}$ & $\begin{array}{c}\text { Arithmetic } \\
\text { mean }\end{array}$ & $\begin{array}{c}\text { I do not } \\
\text { agree at } \\
\text { all }\end{array}$ & $\begin{array}{c}\text { I do } \\
\text { not } \\
\text { agree }\end{array}$ & $\begin{array}{c}\text { To } \\
\text { some } \\
\text { extent }\end{array}$ & Agreed & $\begin{array}{c}\text { Very } \\
\text { agree }\end{array}$ & Paragraphs \\
\hline \multicolumn{7}{|c|}{ Eighth Axis: Community Outcomes } \\
\hline $\mathbf{0 . 9 7 \%}$ & 0.56 & 4.60 & 0 & 0 & 1 & 10 & 19 & $\mathbf{1}$ \\
\hline $\mathbf{0 . 9 3} \%$ & 0.73 & 4.57 & 0 & 1 & 1 & 8 & 20 & $\mathbf{2}$ \\
\hline $\mathbf{0 . 8 0} \%$ & 0.80 & 4.33 & 0 & 0 & 6 & 8 & 16 & $\mathbf{3}$ \\
\hline $\mathbf{0 . 9 7} \%$ & 0.56 & 4.40 & 0 & 0 & 1 & 16 & 13 & $\mathbf{4}$ \\
\hline $\mathbf{0 . 9 3} \%$ & 0.72 & 4.40 & 0 & 1 & 1 & 13 & 15 & $\mathbf{5}$ \\
\hline $\mathbf{0 . 8 0} \%$ & 0.79 & 4.30 & 0 & 0 & 6 & 9 & 15 & $\mathbf{6}$ \\
\hline $\mathbf{0 . 8 3} \%$ & 0.85 & 4.37 & 0 & 1 & 4 & 8 & 17 & $\mathbf{7}$ \\
\hline $\mathbf{0 . 8 9} \%$ & 0.72 & 4.42 & & \multicolumn{7}{|c|}{ Total } & &
\end{tabular}




\begin{tabular}{|c|c|c|c|c|c|c|c|c|}
\hline $\begin{array}{c}\text { Agreement } \\
\text { \%Rate }\end{array}$ & $\begin{array}{l}\text { standard } \\
\text { deviation }\end{array}$ & $\begin{array}{c}\text { Arithmetic } \\
\text { mean }\end{array}$ & $\begin{array}{l}\text { I do not } \\
\text { agree at } \\
\text { all }\end{array}$ & $\begin{array}{l}\text { I do } \\
\text { not } \\
\text { agree }\end{array}$ & $\begin{array}{c}\text { To } \\
\text { some } \\
\text { extent }\end{array}$ & Agreed & $\begin{array}{l}\text { Very } \\
\text { agree }\end{array}$ & Paragraphs \\
\hline \multicolumn{9}{|c|}{ Ninth Axis: Business Results } \\
\hline $0.83 \%$ & 0.77 & 4.40 & 0 & 0 & 5 & 8 & 17 & 1 \\
\hline $0.90 \%$ & 0.73 & 4.47 & 0 & 0 & 4 & 8 & 19 & 2 \\
\hline $0.90 \%$ & 0.67 & 4.40 & 0 & 0 & 3 & 12 & 15 & 3 \\
\hline $0.77 \%$ & 0.82 & 4.23 & 0 & 0 & 7 & 9 & 14 & 4 \\
\hline $0.80 \%$ & 0.82 & 4.43 & 0 & 0 & 6 & 5 & 19 & 5 \\
\hline $0.83 \%$ & 0.77 & 4.43 & 0 & 0 & 5 & 7 & 18 & 6 \\
\hline $0.84 \%$ & 0.76 & 4.39 & \multicolumn{5}{|c|}{ Total } & \\
\hline
\end{tabular}

1. Leadership Hub: From table (2) above, it is clear that the performance evaluation of the driving axis has achieved a total arithmetic mean (4.43) that there is very high acceptance by the senior and middle administrations in the center of the directorate of research sample, and that what confirms the accuracy of the answers is the small overall standard deviation value of this axis (0.78). The ratio of the agreement of the upper and middle administrations with the paragraphs of this axis $(83 \%)$ proves that the agreement ratio is very high and the directorate should achieve these paragraphs, which are called the opportunities for improvement.

2. The strategy's focus: The table also shows that the opportunities for performance evaluation of the strategy axis have achieved a total arithmetic mean (4.19) that there is a very high acceptance of these opportunities by the senior and middle administrations in the center of the Directorate's research sample. The accuracy of the answers confirms the small value of the total standard deviation of this axis (0.84), and the ratio of the agreement of the upper and middle administrations with the opportunities for improvement of this axis (77\%), which proves that the rate of agreement is very high and the Directorate should achieve these opportunities.

3. Human Resources Hub: It is clear from table (2) that the performance evaluation of the human resources axis has achieved a total arithmetic average (4.35), which means that there is a very high acceptance of these opportunities by the senior and middle administrations in the center of the Directorate, the sample of research. The accuracy of the answers confirms the small value of the total standard deviation of this axis $(0.78)$, and the ratio of the agreement of the upper and middle administrations with the opportunities for improvement of this axis $(0.84 \%)$, which proves that the rate of agreement is very high and the Directorate should achieve these opportunities.

4. The focus of partnerships and resources: It is clear from table (2) that the performance evaluation of the focus of partnerships and resources has achieved a total average of (4.29), which means that there is very high acceptance of these opportunities by the senior and middle administrations in the center of the Directorate, sample research. The accuracy of the answers confirms the small value of the total standard deviation of this axis (0.80), and the ratio of the agreement of the upper and middle administrations with the opportunities for improvement of this axis $(0.85 \%)$, which proves that the rate of agreement is very high and the Directorate should achieve these opportunities.

5. The focus of operations and services: Table (2) shows that the performance evaluation of the operations and services axis has achieved a total arithmetic mean (4.24), which means that there is a very high acceptance of these opportunities by the senior and middle administrations in the center of the Directorate of Research Sample. The accuracy of the answers confirms the small value of the total standard deviation of this axis 
(0.81), and the ratio of the agreement of the upper and middle administrations with the opportunities for improvement of this axis $(0.81 \%)$, which proves that the rate of agreement is very high and the Directorate should achieve these opportunities.

6. Customer score: As shown in Table (2) the performance evaluation of the client's results focus has achieved a total of 4.40 and this means that these opportunities are very highly accepted by the senior and middle departments of the department's research sample center. The accuracy of the answers confirms the small value of the total standard deviation of this axis (0.74), and the ratio of the agreement of the upper and middle administrations with the opportunities for improvement of this axis $(0.87 \%)$, which proves that the rate of agreement is very high and the Directorate should achieve these opportunities.

7. The core of the results of the two currencies: It is clear from table (2) that the performance evaluation of the focus of the results of the workers achieved a total arithmetic mean (4.43), which means that there is a very high acceptance of these opportunities by the upper and middle administrations in the center of the directorate, the sample of the research. The accuracy of the answers confirms the small value of the total standard deviation of this axis (0.68), and the ratio of the agreement of the upper and middle administrations with the opportunities for improvement of this axis $(0.91 \%)$, which proves that the ratio of agreement is very high and the Directorate should achieve these opportunities.
8. The focus of society's results: From table (2) above, it is clear that the performance evaluation of the society's results axis has achieved a total of (4.42) arithmetic mean that there is a very high acceptance of these opportunities by the senior and middle administrations in the center of the directorate, the sample of research. The accuracy of the answers confirms the small value of the total standard deviation of this axis (0.72), and the ratio of the agreement of the upper and middle administrations with the opportunities for improvement of this axis $(0.89 \%)$, which proves that the rate of agreement is very high and the Directorate should achieve these opportunities.

9. Business Results Hub: Table (2) also shows that the performance evaluation of the business results focus has achieved a total arithmetic mean (4.39) that there is a very high acceptance of these opportunities by the senior and middle administrations in the department center of the research sample. The accuracy of the answers confirms the small value of the total standard deviation of this axis (0.76), and the ratio of the agreement of the upper and middle administrations with the opportunities for improvement of this axis $(0.84 \%)$, which proves that the rate of agreement is very high and the Directorate should achieve these opportunities.

\section{Third: Analyzing the differences between the axes}

when analyzing the differences between the nine axes using the variance analysis as in table (3), the researcher obtained the following results:

Table (3) Analysis of the discrepancy between the ANOVA standards

\begin{tabular}{|c|c|c|c|c|c|c|}
\hline \multirow{2}{*}{$\begin{array}{r}\text { Level of } \\
\text { significance } \\
P\end{array}$} & \multicolumn{2}{|r|}{ Value F } & \multirow{2}{*}{$\begin{array}{r}\text { Mean } \\
\text { Square } \\
\text { M.S }\end{array}$} & \multirow{2}{*}{$\begin{array}{r}\text { Degree of } \\
\text { Freedom } \\
\text { D.F }\end{array}$} & \multirow{2}{*}{$\begin{array}{r}\text { Sum } r \text { of } \\
\text { square } \\
\text { S.S }\end{array}$} & \multirow{2}{*}{$\begin{array}{r}\text { Source of variation } \\
\text { S.V }\end{array}$} \\
\hline & calculated & $\begin{array}{r}\text { Tabular } \\
0.01\end{array}$ & & & & \\
\hline \multirow[t]{3}{*}{0.000} & 9.849 & 3.78 & 0.543 & 13 & 7.056 & Between standards \\
\hline & & & 0.055 & 16 & 0.882 & Within \\
\hline & & & & 29 & 7.938 & Total \\
\hline
\end{tabular}

It is clear from table 3 that there are significant differences between the axes (EFQM) as the value calculated to (F) is greater than its tabular counterpart (99\%) at (0.01) and at a degree of freedom (D.F) between the axes (13) and (D.F) at (16), it represents the test $(\mathrm{t})$. With the degree of freedom of error, the average error boxes $\left(0.882=s_{e}^{2}\right)$ are used in the Standard Error Equation (Sd) to test the difference between the two axes. 


\section{Fourth: Descriptive analysis of research}

This analysis includes clarifying the relationship between the two research variables, as performance of the three areas (strategic, operational, functional) can be evaluated according to the application of the EFQM to the Directorate and Table (4) will show a detailed presentation of the results of the three levels of performance in the Directorate as the EFQM axes were distributed). In terms of the corresponding performance areas (strategic, operational, functional) and the following :

Table (4) EFQM Performance Domain Results

\begin{tabular}{|c|c|c|c|c|c|c|c|}
\hline $\begin{array}{c}\text { Performance } \\
\text { \%gap }\end{array}$ & $\begin{array}{c}\text { Gap } \\
\text { per } \\
\% \text { axis }\end{array}$ & $\begin{array}{c}\text { percentage } \\
\%\end{array}$ & $\begin{array}{c}\text { Arithmetic } \\
\text { mean }\end{array}$ & questions & $\begin{array}{c}\text { Axis } \\
\text { sequence }\end{array}$ & $\begin{array}{c}\text { Axes } \\
\text { (EFQM) }\end{array}$ & $\begin{array}{c}\text { the } \\
\text { performance }\end{array}$ \\
\hline \multirow{4}{*}{$18 \%$} & $17 \%$ & $83 \%$ & 4.43 & 9 & 1 & Leadership & \multirow{4}{*}{$\begin{array}{c}\text { Strategic } \\
\text { performance }\end{array}$} \\
\hline & $23 \%$ & $77 \%$ & 4.19 & 7 & 2 & The strategy & \\
\hline & $15 \%$ & $85 \%$ & 4.29 & 10 & 4 & $\begin{array}{c}\text { Partnerships } \\
\text { and } \\
\text { resources }\end{array}$ & \\
\hline & $16 \%$ & $84 \%$ & 4.39 & 6 & 9 & $\begin{array}{l}\text { Business } \\
\text { results }\end{array}$ & \\
\hline \multirow{3}{*}{$14 \%$} & $19 \%$ & $81 \%$ & 4.24 & 7 & 5 & $\begin{array}{l}\text { Operations } \\
\text { and services }\end{array}$ & \multirow{3}{*}{$\begin{array}{l}\text { Operational } \\
\text { performance }\end{array}$} \\
\hline & $13 \%$ & $87 \%$ & 4.40 & 7 & 6 & $\begin{array}{c}\text { Customer } \\
\text { results }\end{array}$ & \\
\hline & $11 \%$ & $89 \%$ & 4.42 & 7 & 8 & $\begin{array}{l}\text { Community } \\
\text { Outcomes }\end{array}$ & \\
\hline \multirow[b]{2}{*}{$13 \%$} & $16 \%$ & $84 \%$ & 4.35 & 9 & 3 & HR & \multirow[b]{2}{*}{ Functionality } \\
\hline & $9 \%$ & $91 \%$ & 4.43 & 7 & 7 & $\begin{array}{c}\text { Employee } \\
\text { results }\end{array}$ & \\
\hline $15 \%$ & $15 \%$ & $85 \%$ & 4.35 & & \multicolumn{3}{|c|}{ Overall performance } \\
\hline
\end{tabular}

The results showed that the focus of the workers' results achieved the highest rate of agreement $(91 \%)$, which means the least gap $(9 \%)$, while the strategy axis came with the lowest percentage agreement $(77 \%)$ and the highest gap by $(23 \%)$. Based on these results, the Directorate achieved the percentage of the extent of the agreement with respect to the overall performance level $(85 \%)$ and the total gap (15\%), the strategic performance achieved the highest gap (18\%), followed by the operational performance with a gap of $(14 \%)$ and the job performance received the lowest gap (13\%).

\section{SECTION FOURTH / CONCLUSIONS AND RECOMMENDATIONS}

First: Conclusions

1. The research shows that the Directorate does not rely on a system to evaluate its institutional performance, depending on the traditional method of evaluating the performance of workers for the purpose of the allowance only.

2. The resolution on the nine axes of the EFQM showed the results of the Directorate's reality, the research sample, as an integrated framework for its application in any Iraqi organization seeking to diagnose the strengths and weaknesses of its strengths to develop suitable solutions to improve its performance and improve its 
performance, as it is considered one of the modern integrated and advanced administrative methods.

3. The results of the resolution on the axes of the EFQM model showed that there are gaps in all axes, and the highest gap in the strategy axis followed by the operations and services axis and the leadership axis and the other axes respectively, which affected the quality of the performance of the Directorate, the research sample and these gaps came for several reasons, the most prominent of which were:

- A weak comparison of the objectives achieved with those established for the identification of performance indicators with the clear definition of the cause and effect relationship.

- Environmental, health and occupational safety quality standards are not applied which affect employees, customers, and the community.

- Does not adopt a mechanism to disseminate a culture of creativity, which is the basis of feedback in the EFQM model, making it a work approach to support ideas and improve performance.

- Do not adopt a questionnaire to measure employee satisfaction and express their opinions for improvement, development and creativity.

- Do not adopt a questionnaire to measure customer satisfaction and express their opinions for the purpose of improving the services provided to them by them.

4. The results showed that the application of the institutional performance appraisal model has a role to play in improving the quality of performance in its three areas (strategic, operational, functional) since its application by the Directorate of Research Sample will contribute to strengthening strengths and exploiting weaknesses as opportunities for improvement.

5. The results of the study showed that there is an influence on the axes of the institutional performance evaluation model in evaluating the performance of the Directorate's research sample.

6. The findings of the resolution adopted by the researcher in the study to improve the quality of performance showed that there is a very high agreement by a sample of senior and middle administrations and the quality team in the Directorate, the research sample on the improvement opportunities proposed by the researcher for each of the EFQM axes.

\section{Second: Recommendations}

1. The Directorate of Research Sample should adopt the EFQM as a system for evaluating its performance as a method for periodically evaluating the Directorate.

2. Publishing a culture of evaluating institutional performance using the EFQM model in the Directorate of Research Sample as one of the modern integrated and advanced administrative methods by conducting courses, workshops and seminars in all its forms and indicating its importance in diagnosing strengths for enhancing them and diagnosing weaknesses (opportunities for improvement) to develop appropriate solutions. This enables the Directorate to sample research from continuing learning, creativity and innovation activities.

3. The Directorate urged the research sample to improve the quality of its performance by forming a team to improve each of the three areas of performance (strategic, operational, functional). To reduce or eliminate the performance gap by adopting the results of the survey lists for the nine axes of the EFQM in this research, the results have shown that these axes are classified according to the three areas.

\section{REFERENCE}

\section{A- BOOKS}

1. Armstrong, Michael \&Taylor, Stephen, Armstrong's Hand book of Human Resource Management Practice,13th Edition, Graphic raft Ltd., Hong Kong, Untied King Dom, London, 2016.

2. Al-silmi, Ali, (2002), "Department of Excellence Model and Techniques of Contemporary Management in the Knowledge Age," Gharib Publishing and Distribution House, Cairo.

\section{B- MASTER \& THESIS}

3. Al Dujaili, AlaaAbd Al Hady Hassan, (2017), " Evaluation of Regulatory Performance in the Balanced Performance Card - Comparative Diagnostic Research in 
the Municipalities of Salah al-Din Governorate", Unpublished Diploma Research, Faculty of Administration and Economics, Baghdad University.

4. Al-Madhoun, Mahmoud Atta Omar, (2014)," Knowledge management processes and their relationship to excellence in institutional performance - Application study to Ministry of Education and Higher Education in Gaza Strip governorates", published master message, Academy of Management and Policy for Higher Studies, Gaza.

5. Al-Nasor, Asma Salem, (2010), "Impact of the organization's characteristics marked in achieving institutional excellence - applied study in the Jordanian Ministry of Higher Education and Scientific Research", published master's message, Faculty of Business - Middle East University.

6. Hegazi, Nahal Musa Shadha, (2016), "Employment and his Relationship with Institutional Excellence - Field Study of NGOs - Gaza Strip", published letter, Faculty of Economics and Administrative Sciences, Al-Azhar University, Gaza.

\section{C- RESEARCH \& ARTICLES}

7. Al-Dojni, IyadYahyaAlwan, (2010), "The Role of the Institutional Evaluation Process in Promoting Quality Culture in the Universities of the Gaza Strip from the viewpoint of the Evaluation Team", published research.

8. Al-soudi, Moussa Ahmed, (2008), "Impact of Applying the Concept: Comprehensive Quality Management in Regulatory Excellence in Commercial Banks Working in Jordan," The Jordanian Journal of Local Business Administration, No. 3.

9. Buyukozkan, Gülçin\&Karabulut, Yagmur, (2018), "Sustainability performance evaluation: Literature review and future directions “,Journal of Environmental Management, available At : https://www.sciencedirect.com/science/article/pii/S03014 $\underline{79719309491}$

10. Dahkoul, Zuheir Mohammed, (2018), The Impact of Performance Evaluation on Employee Performance, Moderating Role of Organizational Standards :, European Journal of Business and Management, European Journal of Business and Management.
11. Mohammed, Bouari Burhan, (2017), " Evaluation of the Performance Efficiency of Health Institutions in Erbil City - Application Study at the Rizkari Educational Hospital for the period 2014 - 2016", Publication Research, Al Anbar University Journal for Economic and Administrative Sciences, Al Majd (9), issue (19). 